Cambodia in 2013: (No) Country for Old Men?

Author(s): Duncan Mccargo

Source: Asian Survey, Vol. 54, No. 1, A Survey of Asia in 2013 (January/February 2014), pp. 71-77

Published by: University of California Press

Stable URL: http://www.jstor.org/stable/10.1525/as.2014.54.1.71

Accessed: 02/11/2014 10:04

Your use of the JSTOR archive indicates your acceptance of the Terms \& Conditions of Use, available at http://www.jstor.org/page/info/about/policies/terms.jsp

JSTOR is a not-for-profit service that helps scholars, researchers, and students discover, use, and build upon a wide range of content in a trusted digital archive. We use information technology and tools to increase productivity and facilitate new forms of scholarship. For more information about JSTOR, please contact support@ jstor.org. 


\title{
Cambodia in 2013
}

\author{
(No) Country for Old Men?
}

\begin{abstract}
Cambodia in 2013 was dominated by close-fought national elections on July 28, only narrowly won by the ruling Cambodian People's Party after an unexpectedly strong showing by the opposition. Generational change was a major theme of the year, seen in the growing activism of youth and the deaths of several prominent figures.
\end{abstract}

KEYWORDS: Cambodia, elections, urbanized villagers, monarchy

The yeAr 2013 BEgAN in CAMBODia on a somber note, as preparations gathered pace for the elaborate funeral of former King Norodom Sihanouk in early February. Sihanouk's passing in October 2012, just short of his 9oth birthday, not only marked the end of an era stretching back to colonial times; it also meant the end of the Cambodian monarchy as an independent locus of power, capable of mediating between conflicting politicians. Sihanouk's chosen successor, his unmarried and heirless son Sihamoni (age 60), has struggled to assert his authority and relevance since being crowned in 2004 . During 20I3, that relevance was to be repeatedly tested. In the event, the final phase of Sihanouk's funeral was not attended by the anticipated one million mourners, partly because the government sealed off the area around the Royal Palace to curtail the numbers taking part. ${ }^{1}$ These moves illustrated long-serving Prime Minister Hun Sen's apparent determination further to undercut the standing of the monarchy and to concentrate power in his own hands.

Duncan McCargo is Professor of Southeast Asian Politics, University of Leeds, U.K., and Senior Research Affiliate, Weatherhead East Asian Institute, Columbia University. He thanks his assistants and informants in Cambodia, as well as Joseph Liow, Ann Marie Murphy, Eastina Tan, and Kheang Un. Email: <d.j.mccargo@leeds.ac.uk>.

I. "King Sihanouk's Funeral Procession," CNN, February I, 20I3, <http://ireport.cnn.com/docs/ DOC-9I88I8>; "Norodom Sihanouk's Glorious Goodbye," Phnom Penh Post, February 6, 2013.

Asian Survey, Vol. 54, Number I, pp. 7I-77. ISSN 0004-4687, electronic ISSN 1533-838X. (C) 2014 by the Regents of the University of California. All rights reserved. Please direct all requests for permission to photocopy or reproduce article content through the University of California Press's Rights and Permissions website, http://www.ucpressjournals.com/reprintInfo.asp. DOI: I0.I525/AS.20I4.54.I.7I. 
Death also stalked Case o02, the trial of former Khmer Rouge regime leaders held under the auspices of the Extraordinary Chambers in the Courts of Cambodia (ECCC), a hybrid international tribunal. ${ }^{2}$ Former Foreign Minister Ieng Sary died in March, aged 87, leaving only two remaining defendants: Nuon Chea (87) and Khieu Samphan (82). Ieng Sary's wife Ieng Thirith (8I), originally the fourth defendant in the case, was discharged in September 2012 on the grounds of mental incapacity to stand trial. Khieu Samphan's legendary lawyer Jacques Vergès died in Paris in August 20I3, himself aged 88. The resignation of International Co-Prosecutor Andrew Cayley in September was another blow for the beleaguered Tribunal, which had been beset by funding problems, strike actions by its national staff, and tense relations between the U.N. and the Cambodian government over the prospects for further indictments of prominent Khmer Rouge figures. After closing statements in Case 002/I (the segment of Case 002 dealing primarily with widespread forced evacuations under the Khmer Rouge) were held in October, the future of the ECCC was unclear; some argued that if these elderly defendants were convicted in the first segment of the case, there was little to be gained by continuing the process.

Many elements from King Sihanouk's ceremony were adapted shortly afterward for the lavish funeral of Hun Sen's father, Hun Neang, who also died at the age of $89 .{ }^{3}$ Regional leaders including Vietnamese Prime Minister Nguyen Tan Dung and former Thai Prime Minister Thaksin Shinawatra both traveled to Cambodia to pay their respects on July I2. The demise of Hun Sen's father so close to the 2013 general election was widely deemed inauspicious for the ruling party.

\section{DOMESTIC POLITICS}

The year's politics centered around the general election held on July 28 . Cambodian elections since 1993 have frequently been mired in controversy, but given the strong showing of the ruling Cambodian People's Party (CPP) in both the 2008 general election and the 2012 commune elections, the CPP was widely expected to win comfortably in 20I3. International bodies such as the EU decided not to send teams of election observers, in part because they

2. For detailed updates and analyses on the progress of the Tribunal, see <http://www.cambodia tribunal.org/> and <http://krtmonitor.org/>.

3. Cambodia Daily, July 19, 2013. 
were reluctant to rubber-stamp a foregone conclusion. But in the event, the election proved dramatically illustrative of seismic changes in Cambodian society that are sure to have lasting ramifications.

Just two days after Hun Neang was carried to his final resting place, the streets of Phnom Penh were again crowded with well-wishers. This time hundreds of thousands of people turned out to greet veteran opposition leader Sam Rainsy, who returned to Cambodia from exile just in time for the final week of campaigning. ${ }^{4}$ Acting on Hun Sen's instructions, King Sihamoni had granted Rainsy a royal pardon, but he was not permitted to register as a candidate. The election proved a standoff between just two parties, the $\mathrm{CPP}$ - in effect the dominant power group since 1979-and the Cambodian National Rescue Party (CNRP), led by former Finance Minister Rainsy. CNRP was formed in 20I2, the result of a merger between the eponymous Sam Rainsy Party and the Human Rights Party led by Kem Sokha. In 2008 the two parties had gained 26 and three seats, respectively, in the I23-member National Assembly, dwarfed by the CPP's 90 seats.

While urban dwellers generally favored the opposition, the CPP appeared to have built up a bedrock of support in rural areas, especially in the lowland provinces around Phnom Penh, which had benefited from rapid economic growth over the past two decades. Both parties campaigned on the basis that Cambodia was a nation of farmers. As in previous elections, the CPP invoked the legacy of January 7, 1979, the day on which the Khmer Rouge was removed from power. In his speeches, Hun Sen stressed that the CPP had brought peace, order, and development to the country, asserting that the only alternative to CPP rule was a return to civil war. Hun Sen had previously indicated that he intended to remain prime minister until 2026.

By contrast, the CNRP sought to "rescue" Cambodia from the clutches of the CPP. As ever, Sam Rainsy invoked ethnically charged rhetoric about yuon (the influence of the Vietnamese) designed to highlight the CPP's close ties with Hanoi. ${ }^{5}$ But the CNRP also announced a seven-point populist

4. "Supporters Mob Cambodia's Opposition Leader Sam Rainsy on Return from Exile," Guardian, July 19, 2013, <http://www.theguardian.com/world/2013/jul/rg/cambodia-oppositionleader-rainsy-return-exile>.

5. See Kheang Un, “The Cambodian People Have Spoken,” New York Times, August 9, 20I3, <http://www.nytimes.com/20I3/o8/Io/opinion/global/the-cambodian-people-have-spoken.html?_ $\mathrm{r}=\mathrm{I} \&>$. 
manifesto, pledging to raise wages for both workers and government employees and to reduce the price of basic goods such as oil, fertilizer, and electricity.

In Phnom Penh, both parties mobilized young people to front their campaigns: banner-waving youths on motorbikes cruised the city in packs, especially in the evenings, while the CPP stationed groups of chanting students at key locations, especially near the Independence Monument. ${ }^{6}$ Woe betide any passers-by sporting opposition logos: they were pulled over and their CNRP stickers torn off. While the CPP campaign was well-equipped and fundedmost of those taking part were paid-CNRP activists were overwhelmingly volunteers. The CNRP campaigned using the simple refrain "Change!" (Do!), leaving the CPP to respond rather lamely, "No Change!" (Min Do!). Non-governmental organization (NGO) leader Ou Virak described the CPP campaign as "weak, robotic and heartless" compared with the more impassioned and spontaneous electioneering of the CNRP. ${ }^{7}$ But the same paradox afflicted both campaigns: kids out on the streets, dancing and cheering beneath images of old men. Most CPP posters featured the jaded triumvirate of Chea Sim (8o), Hun Sen (6o), and Heng Samrin (79), while those of the CNRP depicted Sam Rainsy (64) clasping hands with Kem Sokha (6o). For all the façade of youth, this was a campaign featuring lots of aging faces and well-worn themes.

Neither party seemed really to grasp the changing dynamics of the electorate. While most Cambodians nominally live in rural areas, villagers of working age often spend much of the year selling their labor in and around Phnom Penh, in neighboring Thailand, or even further afield. Although they vote in the countryside, they live and work in cities, and their dreams and aspirations are almost entirely urban. These "urbanized villagers" feel no debt of gratitude to the CPP for having developed the nation, ${ }^{8}$ and the $70 \%$ of the population aged under 30 have no memories of the collective renewal following the 1975-79 Khmer Rouge era. They were repelled by the emotionalism of slogans such as "If You Love/If You Pity/If You Like/If You Trust/

6. This and the following paragraphs are based on the author's fieldnotes, Phnom Penh, July 2I-28, $20 \mathrm{I3}$.

7. Author interview with Ou Virak, president of the Cambodian Center for Human Rights, Phnom Penh, July 23, 2013.

8. For the first coinage of this term, see Naruemon Thabchumpon and Duncan McCargo, "Urbanized Villagers in the 20I0 Thai Redshirt Protests: Not Just Poor Farmers?" Asian Survey 51:6 (20II), pp. 993-IOI8. 
Hun Sen/Vote CPP," and by the ubiquitous ruling party logos on the villas and luxury cars of regime beneficiaries.

On the eve of the election, hundreds of thousands of people traveled back from the capital to their villages to vote, the majority fired up for "change" and eager to tell their families and neighbors about the triumphal reception that greeted Sam Rainsy on his return to Phnom Penh. ${ }^{9}$ His return, the biggest political development in Cambodia for many years, was completely ignored by TV stations, which are all owned either by the government or by regime cronies. The CPP's attempts to block coverage of the opposition backfired badly, as people turned for political information increasingly to alternative and social media, as well as to Radio Free Asia and VOA (Voice of America).

In the end, however, no party ran the kind of professional election campaign that most other Southeast Asian countries take for granted. The CPP was expecting to win, while the CNRP was expecting to lose, and their campaigns reflected these assumptions. One prominent NGO leader complained that Sam Rainsy was "allergic" to strategic thinking, expending energy campaigning in areas such Sihanoukville with virtually no seats to be won..$^{10}$ The director of a radio station claimed that neither party had a well-thought-out media strategy. ${ }^{11}$ Nevertheless, huge numbers of voters became passionately engaged with the election, breathing unexpected life into the process.

The results confounded most pundits. The CPP secured 3,235,969 votes ( $49 \%$ of the popular vote) and 68 seats, down 22 from the 2008 elections. The CNRP garnered 2,946,176 votes (44\%) and 55 seats, 26 more than the Sam Rainsy and Human Rights Parties combined in 2008. ${ }^{12}$ Many prominent CPP figures lost their seats, while Hun Sen's youngest son Hun Many initially failed to win election, a symbolic blow to the premier's dynastic ambitions. The royalist party FUNCINPEC, victors in 1993, failed to gain a single seat, further evidence of the monarchy's precipitate decline. Rather than celebrate the CNRP's unprecedented successes and seek to maximize

9. Author's fieldnotes, Kandal and Prey Veng Provinces, July 27-28, 2013.

Io. Ou Virak interview. On Sam Rainsy's “whirlwind” provincial tour, see Cambodia Daily, July 23,24 , and 25, 2013.

II. Author interview with Pa Nhuon Teang, Radio Voice of Democracy, Phnom Penh, July 22, $2 \mathrm{OI} 3$.

I2. For full results mapped by province, see <http://electionresults.cambodianvotervoice.org/>. 
their impact, Sam Rainsy immediately rejected the election results, alleging that over one million names had been removed from voter lists. He appealed to the U.N. and King Sihamoni to intervene, and announced that the CNRP would boycott the National Assembly.

Despite these pleas, Sihamoni promptly approved the election results, and Hun Sen was reappointed prime minister unopposed when the National Assembly reopened on September 23, 20I3. The CNRP responded by organizing a series of protest rallies and called for the creation of a Truth Commission "to provide justice to voters." While these rallies passed without incident, the wisdom of Rainsy's approach was open to question, since the international community had a limited appetite for further interventions in Cambodian politics, and the CPP victory was now a fait accompli.

\section{ECONOMY AND SOCIETY}

Outwardly, Cambodia's economy was strong during the year, outperforming many neighboring countries in the region. Gross domestic product (GDP) grew by $7.2 \%$ in 20I2, an improvement on previous years; although exports fell, domestic consumption rose by $9.5 \%$. Cambodia also benefited from a surge in foreign direct investment, attracted partly by low wages. Here lay the rub: gross national income per capita in Cambodia (\$880) was much closer to that of Bangladesh $(\$ 840)$ than to neighboring Laos $(\$ 1,260)$ or Vietnam (\$I,400), let alone Thailand $(\$ 5,2 \mathrm{IO}) .{ }^{13}$

Cambodia's massive income disparities were the Achilles' heel of the CPP: senior government officials and well-connected business figures had become extraordinarily wealthy, leaving the mass of the population far behind. Linked to these disparities were issues of land-grabbing, endemic corruption, and official impunity. The ruling party had paid lip service to these issues. Piecemeal responses had included dispatching groups of university students to undertake land title projects in rural areas, instead of supporting a credible and systematic nationwide program of land registration as urged by international donors. ${ }^{14}$ The government's heavy-handed suppression of dissent over land-grabbing was aptly symbolized by the widely condemned December 2012 jailing of Yorm Bopha, a young mother who played a leading role in

I3. These are World Bank Gross National Income Per Capita (GNIPC) Atlas method figures for 20I2; see <http://data.worldbank.org/indicator/NY.GNP.PCAP.CD/countries>.

I4. Informant interviews, Phnom Penh, July 2013. 
protests against the development of the Boeung Kak Lake area of Phnom Penh by a well-connected company. ${ }^{15}$ Although King Sihamoni was asked to pardon Yorm Bopha before the election, he was apparently prevented from doing so by the government, a further illustration of his limited room for maneuver. In late November, she was released on bail pending a retrial.

\section{REGIONAL RELATIONS}

In recent years, Cambodia's regional relations have been overshadowed by an ongoing border dispute with Thailand over the contested Preah Vihear temple complex, a dispute that degenerated intermittently into a shooting war between 2008 and 20II. The International Court of Justice (ICJ) had ruled in I962 that the 90o-year-old temple belonged to Cambodia, but did not specify who owned the land surrounding the historic site-which was claimed by both sides. On November II, 2OI3, the ICJ awarded Cambodia sovereignty over the whole promontory of Preah Vihear itself, but left the two countries to agree on who owned the adjoining area, including Phnom Trap. ${ }^{16}$ The judgment allowed both sides to claim a measure of victory but was especially welcomed in Phnom Penh. Hun Sen described it as "an important and historic step forward," while reaction from Bangkok was rather muted. ${ }^{17}$ There were predictable calls for ASEAN (the Association of Southeast Asian Nations) to help resolve the residual dispute, but it remains unclear whether the lackluster regional body has either the requisite capacity or the political will to make a difference.

I5. For details and sources, see Free Yorm Bopha website, <http://freether5.wordpress.com/ category/yorm-bopha/>.

I6. For details of the judgment, see the ICJ press release, November II, 2OI3, at <http://www.icjcij.org/docket/files/I5I/I77I4.pdf>.

I7. See "Partial Victory at the ICJ," Phnom Penh Post, November II, 20I3, <http://www. phnompenhpost.com/national/partial-victory-icj>. 